\title{
Forage seed production: 75 years applying science and technology
}

\author{
M.P. ROLSTON ${ }^{1}$, R.J. CHYNOWETH ${ }^{2}$ and A.V. STEWART ${ }^{3}$ \\ ${ }^{1}$ AgResearch Ltd, PO Box 60, Lincoln \\ ${ }^{2}$ Foundation for Arable Research, PO Box 80, Lincoln \\ ${ }^{3}$ PGG Wrightson Ltd, Kimihia Research Centre, Lincoln \\ phil.rolston@agresearch.co.nz
}

\begin{abstract}
Forage seed (brassica, grass and legume species) is the delivery vehicle for new plant genetics to the pastoral sector. Seed production technology associated with the release of the first bred pasture cultivars in the 1930s was largely based around horse-drawn reaper and binders and stationary threshing machines. The development of authenticity and quality controls also started in the 1930s with the NZ Seed Certification Scheme. Management inputs were minimal with closing and harvest dates being the major tools available. Over a 75 year period, seed yields have increased, with top growers now achieving seed yields that are three times greater than those reported 50 to 75 years ago. In the 1950 s, harvest mechanisation developed rapidly and in the 1970s on-farm seed drying was developed. The availability of nitrogen $(\mathrm{N})$ fertiliser was the first major input available for grass seed growers. The paper follows the science and changing recommendations on $\mathrm{N}$ rates and the eventual maximum limit achieved by additional N identified in trials in 2004. From the 1960s onwards, new herbicides have allowed for the control of a wider range of difficult to control weed species, especially the control of other grasses in ryegrass seed crops and broadleaved weeds in white clover. New generation fungicides, insecticides and plant growth regulators have provided improved management tools for increased seed yields. The paper concludes with changes in extension from Government driven (Department of Agriculture) to farmer funded R\&D and extension by the Foundation for Arable Research.
\end{abstract}

Keywords: ryegrass, white clover, brassica, seed production, history

\section{Introduction}

During the past 75 years, forage seed has been the delivery vehicle of new plant genetics to the pastoral sector. The successful evolution of the forage seed industry has had a significant influence on the development of grassland technologies in New Zealand (NZ). This has also contributed to NZ achieving a prominent status in the international grassland community.

Seed production in NZ began with the Banks Peninsula cocksfoot (Dactylis glomerata) industry from 1851 but this died out in the 1930s when disease attacked the crop, and lower cost machine harvesting was introduced on the Canterbury Plains.

Seed production is largely centred on Canterbury, but historically other regions were important especially Southland for Chewings fescue (Festuca rubra) and crested dogstail (Cynosurus cristatus); Marlborough for red clover (Trifloium pratense) and lucerne (Medicago sativa) while Wairarapa, Manawatu and Hawkes Bay all had significant production. In 1947, Southland produced $1240 \mathrm{t}$ of Chewings fescue and $1530 \mathrm{t}$ of dogstail. The area in seed production in 2003/ 04 was 43,380 ha, consisting of 22,600 ha of grass seed, 8500 ha of legumes, 1600 ha of brassicas and radish, 600 ha of triticale and oats, and 280 ha of herbs (chicory and plantain) (AgriQuality 2004). Forage maize seed is largely imported. Reviews that relate to the NZ herbage seed industry include those by Rolston \& Clifford (1989), Mather et al. (1996), Clifford (1998), Rowarth et al. (1998a) and Pyke et al. (2004).

\section{Seed Certification and Seed Testing}

One of the world's first authenticity and quality control systems was developed in New Zealand. This began with the introduction of herbage seed certification in 1929 for perennial ryegrass (Lolium perenne) and browntop (Agrostis capillaris) (Hampton \& Scott 1990). This scheme was soon extended to cover cocksfoot, white clover (T. repens) and red clover.

Seed Certification provides a set of rules to track and maintain genetic purity, based on phenotypic expression, of cultivars during production. Seed line physical purity and germination are assessed by seed testing. The Official Seed Testing Station (Department of Agriculture) was opened in 1928 in Palmerston North and later became the National Seed Laboratory, run by AgriQuality (Ministry of Agriculture \& Forestry).

As crossing may occur between brassica species, their seed production was regionalised for many years, partly to avoid contamination by naturally occurring wild turnip. Turnips and swedes were restricted to Central Otago, rape and kale were grown in Canterbury and northern Otago and thousand-headed kale in coastal Otago (Claridge 1972). Production has been progressively reduced in Otago and become 
concentrated in Canterbury. In the early 2000 s, to achieve the isolation distances required between forage and hybrid vegetable brassica species (often 750 and $1500 \mathrm{~m}$ ) an internet based crop registration system known as SCID (Seed Certification Isolation Distance) was developed and is now run by AqriQuality (the seed certification agency).

Management of Seed Certification was transferred from central Government to the industry with the Seed Quality Management Authority (SQMA) assuming control in 1993. SQMA contracts AgriQuality to run the scheme. Participation in the NZ Seed Certification Scheme is voluntary, and unlike most countries there is no Seed Law in NZ. However, growers enter almost all crops into the Seed Certification system, except some annual crops and Italian ryegrass where about $50 \%$ are entered. Several independent seed testing laboratories are accredited by ISTA (International Seed Testing Association) and have provided international seed analysis certificates since 1994 .

\section{Breeding/Species Available}

The Department of Agriculture established a research station at Palmerston North in 1926, which became DSIR (Department of Scientific and Industrial Research) Grasslands in 1936 (Levy 1970). The expansion of the herbage seed industry in the 1930s followed the establishment of Grasslands and the release of New Zealand (NZ) bred cultivars. The first of these, "NZ white clover' later renamed as 'Grasslands Huia' was released in 1930 and is still the largest volume white clover cultivar grown for seed in NZ. 'Certified perennial ryegrass' later renamed as 'Grasslands Ruanui' was also released in 1930 and was grown for a period of 65 years. These cultivars were followed by 'Certified cowgrass' ('Grasslands Hamua' red clover) (1932), 'Certified Italian ryegrass' (L. multiflorum 'Grasslands Paroa') (1938), and 'Certified timothy' (Phleum pratense) (1947). These cultivars (and several others bred before 1984 by DSIR Grasslands) are known as 'public cultivars' because any seed grower could produce them without a production contract.

From the 1950s a wider range of species were bred, mostly by DSIR Grasslands, and entered into seed production; 'Grasslands Apanui' cocksfoot (1953), 'Grasslands Matua' prairie grass (Bromus willdenowii) (1973), 'Grasslands Roa' tall fescue (Festuca arundinacea (syn. Schedonorus phoenix)) (1980) 'Grasslands Puna' chicory (Chicorium intybus) (1987) and 'Grasslands Lancelot' plantain (Plantago lancelota) (1993). The breeding of a hybrid ryegrass was a NZ first with the release of short rotation (H1) ryegrass 'Grasslands Manawa' (L. x boucheanum) in 1947, while tetraploids ('Grasslands Pawera' red clover and
'Grasslands Tama' westerwolds ryegrass) became available in 1968. In the period 1960 to 1990 cultivars of browntop, Bromus, Caucasian clover (T. ambiguum), Lotus, Paspalum, Phalaris and Yorkshire fog (Holcus lanatus) were bred for lower soil fertility or stress environments. These "alternative" species were expected to lead to an expansion of the herbage seed industry (Rolston et al. 1988) but this did not happen. Instead demand, and therefore production, is dominated by ryegrass, white clover and tall fescue.

Seed of forage brassicas such as turnips ( $B$. campestrus), rapes (B. rapa), kales (B. oleracea) and swedes (B. napus) were traditionally imported from the UK. Although seed production occurred to a limited extent before 1939, the reduced seed supplies caused by World War II stimulated New Zealand to become self sufficient in forage brassica seed. This required a program initiated by DSIR (and later continued by Crop and Food), in close partnership with seed companies, to maintain and improve the range of brassicas, particularly for disease and pest resistance. This resulted in a wide range of cultivars including Greenglobe, Yorkglobe, Kapia and Manga turnip; Moana, Rangi and Wairangi rape; Calder, Sensation and Tina swede; Marrow stem and Giant kale (Palmer 1983).

Prior to 1986, forage species entering seed certification had to be assessed in official agronomic trials and accepted into the National List based on agronomic merit. The elimination of this requirement (and the introduction of Plant Variety Rights) led to both the breeding of many new cultivars and multiplication of overseas cultivars for re-export and local use (Hampton $\&$ Scott 1980). For seed growers the introduction of new white clover cultivars from $\mathrm{NZ}$ and overseas raised the issue of the impact of buried white clover seed on cultivar purity. Research led by Clifford demonstrated that the OECD 2 year paddock history rule was not adequate and a 5 year paddock history 'change-ofcultivar' rule was introduced into Seed Certification in 1984 (Clifford et al. 1995). This was coupled with the development of a buried seed test for growers and seed companies to use when identifying potential paddocks, especially for new high grade seed multiplications.

The availability of overseas cultivars for remultiplication provided opportunities for smaller seed companies. This also encouraged forage plant breeders in NZ to collaborate with overseas seed companies to develop clover cultivars for Europe, and new herbage cultivars for Australia and Argentina/Uruguay.

The Plant Variety Rights (PVR) Act 1973 (replaced by the PVR Act 1987) was initially developed for barley and roses. It was expanded to include all agriculture species in 1981 and this led to a rapid expansion of private plant breeding, especially from three companies; 
Pyne Gould Guinness, Wrightson, and NZ Agriseeds. In 1984, DSIR Grasslands began a system of appointing head licensees, marking the end of new 'public cultivars'. Government funding of breeding herbage cultivars for release stopped in the late 1990s. For seed growers, new cultivars led to new opportunities and choice between growing proprietary cultivars under contract (with price determined before sowing) or the older public cultivars as non-contract seed. The price of public cultivars was subjected to price fluctuations from changing market demand (especially international supply and demand) and exchange rates, especially after the floating of the NZ dollar in 1985. Typically, proprietary prices have been stable between years and in ryegrass have averaged $\$ 1.70$ to $\$ 1.95 / \mathrm{kg}$ (depending on cultivar) while 'Nui' ryegrass prices have fluctuated between $\$ 1.10$ and $\$ 2.00 / \mathrm{kg}$.

Until the mid 1980s NZ based breeding was focused on the domestic market, although seed exports have always been an important activity for the NZ seed industry. This has been especially so for white clover to Europe and Nui perennial ryegrass into the US turf seed trade, favoured because of its very low UV florescence levels and competitive price. Multiplication of overseas cultivars for re-export began in the mid 1980s and gave NZ seed growers a greater range of cultivar choice, especially European white clovers and US turf ryegrass cultivars. However, not all overseas cultivars produced economic seed yields when grown in NZ, especially late flowering European ryegrasses from more northern latitudes. Forage brassicas are also grown for the local market and export including radish and mustard as well as an increasing area of vegetable brassica seed for export.

\section{Smart Seed Technologies}

Rhizobia inoculant seed coatings in legumes, fungicide and insecticide coatings on brassica and grass seeds and the introduction of endophytes (Neotyphodium spp.), all represent a group of 'smart-seed technologies'. "Superstrike" ${ }^{\circledR}$ coated brassicas were developed in the mid 1980s, providing insect and fungal disease protection.

Novel endophytes in ryegrass and tall fescue represent the most recent technological advances in new cultivars (Easton 1999), presenting additional quality standards for growers and seed retailers to incorporate into their practices. 'Endosafe' ryegrass was commercialised in the early 1990s, followed later by ryegrasses with AR1. Endophyte viability in seed usually declines more rapidly than seed viability. Being able to deliver viable endophytes required major adjustments in seed inventory management and changes in seed storage, especially for high grade seed required for further multiplication.

\section{Seed Production}

\section{Mechanisation}

Some of the biggest changes over the past 75 years relate to mechanisation. During the years between World Wars tractors became common. However, farmers were reluctant to do away with their teams of draft horses and it was common for both horses and tractors to be used on farms. The last draft horse teams continued to work on farms until about 1960.

The first self-scouring steel plough and horse drawn reapers were developed in the 1830s (by John Deere and Cyrus McCormick respectively), with the reaper and binder following soon after. In the years which followed, steam power was applied to agriculture and was first used in the form of stationary steam engines for powering the recently developed stationary threshing units. Steam traction engines however had restricted uses within agriculture, mainly due to their size and weight. However, they were ideal for powering stationary threshing units and hauling heavy loads (Wilson 2004).

When the tractor arrived in the early 20th century it did not spell the immediate end of the traction engine with production continuing into the 1920 s where they were used to drive threshing machines in NZ until after World War II. The first tractors in NZ arrived in 1904. It was not until 1910 - 1920 that the smaller, lighter tractors began to arrive in New Zealand. In the between war period, as tractors became more common, implements required change from horse drawn where the farmer walked behind the implement, to tractor-drawn where the operator was in front of the implement. Major advancements took place during the 1930s with the development of pneumatic rubber tyres and specialist implements such as tow-behind header harvesters, which gradually took over from reapers, binders and stationary threshers. Self propelled combines were first developed in the late 1930s.

Approaches to cultivation have changed from traditional ploughing. A 2005 survey of 25 ryegrass seed crops in South Canterbury showed most growers (80\%) used minimum tillage, compared with ploughing $(10 \%)$ and direct drilling (10\%) (FAR 2005).

Traditional harvest systems in white clover resulted in large losses with Trought (1980) reporting a 50\% loss (hand harvest $\mathrm{v}$ machine harvest) and large losses from mowing (Clifford \& McCartin 1985). Methods to reduce losses included cutting with a double reciprocating knife mower and using a "Murphy pickup", but in the mid 1990s these were replaced by direct harvesting of desiccated crops.

In grasses, traditional knife mowers were replaced by disc mowers, and pea-lifter pick-ups by draper pick ups that were able to handle swaths after they had been wet 
by rain. Disc mowing has always been more popular than windrowing, the latter producing bigger windrows that are more vulnerable to wind blow and take longer to dry and which are particularly difficult to handle in wet harvest seasons.

Combine harvesters have become larger, with enclosed driver cabins, and more sophisticated (e.g. grain yield monitors and GPS mapping of yield), although the basic components (pick-up, threshing drum and separation riddles) have remain unchanged. Bagging off from the combine was common until the mid 1950s and was gradually replaced by bulk handling systems, once safe seed moistures were understood. Initially a proportion of lines had disastrous germination collapses from fungal (Aspergillus glaucus) heating due to inexperienced growers harvesting at too high moisture levels.

\section{Seed drying}

The development of seed and grain drying in NZ has been well reviewed by Hill (1999). He pays tribute to the work of Crosbie during the 1960s and early 1970s for introducing many Canterbury farmers to the idea that they could dry and store grain on farm, that they could harvest grain and seed in bulk instead of using bags and harvest their crops earlier if they dried the seed and thereby achieve higher yields.

\section{Seed cleaning}

During the 1980s there was an expansion of both farmer-owned and independent seed cleaning facilities associated with a decline in seed cleaning plants run by the large "Grain and Seed" merchants. This was driven by pressure on seed processing capacity from the development of turf ryegrass seed sales to the USA, the expansion of the Australian seed market and a reduction in the practice of using carry-over seed stocks to supply the market. All these factors require a quick turn around of seed for delivery shortly after harvest. The basic steps in seed cleaning and equipment used have changed little. Screen-air cleaners have developed from simple 2screen to 4-screen machines, with improved selfcleaning of sieves using oscillating rubber balls.

\section{Pollination}

Legumes, brassicas and forage herbs are insect pollinated and the most important pollinators for these forage seed crops are bees. There are approximately 40 known bee species within NZ, of which eight were deliberately introduced, one for honey production and seven for pollination. The honey bee (Apis mellifera) was first introduced in 1839 primarily for honey production, but it quickly became the most important pollinator for the valuable pastoral and horticultural crops grown within NZ.

Four species of bumble bees (Bombus spp.) were introduced from England in 1885 for the pollination of red clover seed crops. Of the species introduced into $\mathrm{NZ}$, three are long tongued and one is short tongued. Long tongued bumble bees are particularly important pollinators of tetraploid red clover (Donovan \& Macfarlane 1984) while short tongued bumblebees are important for other crops, such as white clover, diploid red clover and horticultural crops. Bumble bee numbers rarely approach those required for effective crop pollination and are much harder to manage compared to honey bees. Short tongued bumble bees are currently being reared and sold on a commercial scale in New Zealand. Long tongued bumble bees on the other hand are rarely available although some trapping of nests does occur on a limited scale for red clover seed production.

Alkali bee (Nomia melanderi) and the lucerne leaf cutting bee (Megachile rotundata) were introduced from North America in the early 1970s with the goal of establishing better pollinators for lucerne seed crops. Donovan \& Read (1988) showed that with sufficient bee populations seed yields can be increased dramatically (203 kg/ha in 1981 compared to $687 \mathrm{~kg} / \mathrm{ha}$ in 1982). However, with the reduction in the amount of lucerne production in New Zealand and the disestablishment of DSIR, the populations of these two bee species have plummeted. Both species are potential pollinators of white clover and other field crops. The red clover mason bee (Osmia coerulescens) was introduced in 1995, with the expectation of producing a manageable pollinator for tetraploid red clover. A small population is currently maintained at Lincoln. Research into the management of the red clover mason bee is ongoing but the population is still small (Donovan 2006). With varroa mite (Varroa destructor) arriving within $\mathrm{NZ}$ and reaching the South Island in 2006, the management of honey bees has become more critical. In the future, other bee species may become important pollinators of forage seed crops. On occasion a range of minor insect pollinators, including native insects, may be important in brassica pollination (Brad Howlett, Crop and Food Research, pers. comm.).

\section{Irrigation}

Irrigation can increase seed yields by $37 \%$ (Rolston et al. 1994) and by three fold on lighter soils (FAR unpublished data). Large scale boarder dyke irrigation of mid Canterbury cropping land began with the completion of the $67 \mathrm{~km}$ Rangitata Diversion Race (RDR) in 1945. This provided irrigation water to 66,000 ha in summer and winter water to the Highbank Power Station. During the 1980s, drilling shallow ground 
water bores to provide irrigation increased, initially with wells drilled to $30 \mathrm{~m}$, usually between the coast and State Highway (SH) 1. Since the 1990s, deep well drilling west of SH 1 increased, with some recent wells drilled to $300 \mathrm{~m}$. In Canterbury, it is estimated that more than $70 \%$ of seed crops are currently grown using irrigation, with most of the dryland crops in the higher rainfall zone around Methven and on the clay down-lands of South Canterbury.

\section{Agronomic Management}

In white clover, significant agronomic management developments include the importance of wider rows $(30-45 \mathrm{~cm})$ to provide space for stolons to elongate and flower and understanding the relationship between increased soil moisture and high soil available phosphate enhancing leaf size and decreasing flower numbers (Clifford 1987). Second year white clover seed crops represent about $20 \%$ of the crop (David Harrision, PGG Wrightsons, pers. comm.). These crops require different management to first year crops as identified following a series of field trials (FAR 1999, 2004). Understanding crop form (morphology) and function (physiology) and how plant vegetative and reproductive growth respond to the environment is essential for understanding the management of seed crops (Clifford 1997).

\section{Nutrients}

The importance of $\mathrm{N}$ for increasing seed yields in ryegrass was demonstrated in the 1970s in trials by Field-Dodgson (Langer 1980) and Brown (1980). Later Rowarth et al. (1998b) demonstrated seed yield could be predicted by leaf $\mathrm{N}$ levels before stem elongation. $\mathrm{N}$ applications by growers increased markedly during the $1990 \mathrm{~s}$ from rates of 80 to $120 \mathrm{~kg} \mathrm{~N} / \mathrm{ha}$ to 180 to $300 \mathrm{~kg}$ N/ha. Recent FAR-funded trials have shown that the higher rates of $\mathrm{N}$ being used can sometimes depress yields. Work is currently focused on predicting $\mathrm{N}$ requirements, taking account of late winter soil mineral N levels (McCloy \& Rolston 2005). In white clover, higher soil available $\mathrm{P}$ levels result in increased leaf size and depressed seed yields (Clifford 1985). Sulphur is important for seed weight in clover and mineral requirements for clover seed crops were reviewed by Clifford \& Rolston (1990). Grass seed responses to P, $\mathrm{K}$ and $\mathrm{S}$ may only occur with extreme deficiencies (Rolston et al. 1985). Lime responses are most likely associated with changes in availability of trace elements, e.g. Zn deficiency in over-limed fields (Rolston et al. 1985 ) and B on legume seed crops to improve seed set.

\section{Agrichemicals}

The availability of agrichemicals revolutionised herbage seed production through improved weed control options, reduction of fungal diseases (especially in grasses), control of insect pests (especially in legumes) and plant growth regulators. Agrichemicals are not developed specifically for herbage seed crops but seed growers have benefited from access to chemicals initially developed for cereals and soybeans. Examples include the development of herbicides to control wild oats in cereals and herbicides for grass and broadleaf control in soybean.

\section{Weeds and herbicides}

Weeds are either competitive in the crop reducing seed yield (Rolston \& Archie 1999) and/or are contaminants in seed lines. There are good records on the frequency of ocurrence of weed seeds in seed lots based on National Seed Laboratory records (Rowarth et al. 1990a, b). Only three noxious weed species are prohibited under NZ Seed Certification; nodding thistle (Carduus nutans), wild oat (Avena fatua) and yellow gromwell (Amsinckia calycina) (which is restricted to Otago and Canterbury) (AgriQuality 2005). A number of other species are regarded as undesirable in the international and local seed trade. Growers are heavily discounted for seed lines that contain any dock species (Rumex sp.) or thistles species (Carduus and Cirsium spp.).

Prior to the widespread use of herbicides, cultural controls such as fallowing, improving soil $\mathrm{pH}$ or fertility levels, hand removal of off-types and grazing were used to control weeds.

The first widely used herbicide was 2,4-D developed in 1942 with widespread use in the late 1940s giving grass seed growers a chemical tool for controlling many broadleaf weeds. Clover seed growers had the benefits of 2,4-DB (released in 1947), dinoseb-acetate, paraquat and diaquat (1958) and carbetamimide (1960), bromoxynil (1964) and propyzamide $\left(\operatorname{Kerb}^{\circledR}\right)$ (1965), giving a range of products to control broadleaf and grass weeds. New herbicides for grass seed growers included ethofumesate (Nortron ${ }^{\circledR}$ ) (1969) for Poa annua and annual grass weed control, and the first wild oat (Avena fatua) herbicide difenzoquat (Avenge) (1972). Glyphosate (Roundup ${ }^{\circledR}$ ) was released in the late 1970s for non-selective weed control. From the early 1990s, generic glyphosate products had driven the price down, and glyphosate is widely being used pre-sowing and pre-emergence as a chemical fallow. As easy to kill weeds were controlled, other species became problems, e.g. field pansy (Viola arvensis) (Rowarth et al. 1990b). Residues from herbicides used in wheat and brassica crops can impact on the establishment of new grass or legume seed crops making rotation planning more complex, e.g. trifluralin $\left(\operatorname{Treflan}^{\circledR}\right)$ used for weed control in brassica seed crops. 


\section{Plant growth regulators (PGRs)}

The plant growth regulator, trinexapac-ethyl $\left(\right.$ Moddus $^{\circledR}$ ), became commercially available for use in grass seed crops in the late 1990s and was widely adopted (Pyke et al. 2004). However the history of evaluation and use of PGRs includes paclobutrazole (PP-333) being widely evaluated (Hampton \& Hebblewaite 1984) but not commercialised for NZ grass seed crops. Chlormequat chloride or CCC $\left(\mathrm{Cycocel}^{\mathbb{}}\right)$ also increased ryegrass seed yields (Hampton 1986) and was used by many growers before being displaced by trinexapac-ethyl. Surveys showed a $100 \%$ grower adoption of Moddus ${ }^{\circledR}$ with trials demonstrating yield increases of $50 \%$ in ryegrass (nine trials) and $67 \%$ in tall fescue (six trials) (Rolston et al. 2004). Although growth regulators have been experimented with on brassicas and clovers, they are not generally used for these crops.

\section{Diseases and fungicides}

A number of fungal diseases cause significant yield losses, especially in grasses (Latch 1980) and brassica seed crops. Fungicides are often used to control the brassica diseases Alternaria brassicae and Sclerotinia sclerotiorum as they may reduce yield, germination and seed quality. The diseases clubroot (Plasmodiophora brassicae) and ringspot (Mycosphaerella brassicicola) can also occur on brassica seed crops but good hygiene and the long rotation required between brassica crops helps control these. Stem rust (Puccinia graminis) can cause large yield losses in years of epidemics and Kerse $\&$ Ballard (1989) reported four to five fold increases in seed yield using cyproconazole to control this disease in ryegrass. Blind seed disease, caused by Gleotinia temulenta, reduces germination and the value of seed lots. The incidence of blind seed has reduced in recent years and is attributed to increased $\mathrm{N}$ fertiliser levels (Hampton \& Scott 1980; DeFilippi et al. 1996) and fungicides used as seed treatment or applied at flowering (Rolston, unpublished data). However, it is still a significant problem when conditions are wet and cool during flowering as occurred in the 2004/05 season. Ergot (Claviceps purpurea) occurs as a seed disease in grasses and is common in late flowering ryegrass. No control strategies are available for ergot. Since the 1980s, there has been development of a range of new fungicides and two chemical families have especially have been useful for seed growers. The triazole group; 1982 propiconazole $\left(\right.$ Tilt $^{\circledR}$ ), 1990 tebuconazole

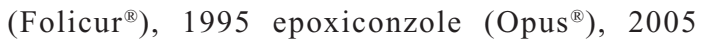
prothioconazole (Proline ${ }^{\circledR}$ ) and more recently the strobilurin group; azoxystrobin (Amistar ${ }^{\circledR}$ ), trifloxystrobin $\left(\right.$ Twist $\left.^{\mathbb{R}}\right)$ and pyraclostrobin $\left(\right.$ Comet $\left.^{\mathbb{B}}\right)$. Mixtures of triazole + strobilurin fungicides have been particularly effective at enhancing seed yields with an average increase of $21 \%$ in nine trials conducted over 8 years (Rolston et al. 2004). The role of fungicides in delaying leaf senescence in ryegrasses and thereby increasing seed yield, in the absence of leaf pathogens, was first reported by Hampton \& Hebblewaith (1984). Today seed yield losses from disease require regular crop monitoring and fungicide usage on all grass and most brassica seed crops.

\section{Pests and insecticides}

Insect pests are a significant problem in legume seed crops (reviewed by Trought 1980). He described the two main insect pests in white clover as clover casebearer moths (Coleophora spp.) and aphids, especially lucerne blue-green aphid (Acyrthosiphon kondoi) and sometimes the pea aphid (A. pisum). In white clover, bromophos insecticide, used to control aphids, increased seed yields by $170 \mathrm{~kg} / \mathrm{ha}$ (24\%) (Trought 1980). Biological control with parasitic wasps has virtually eliminated case-bearer using Bracon variegator and Neochrysocharis spp. (Clifford 1998), and lucerne aphid using Microctonus aethiopoides. In the 1990s, the problem insects had shifted to mirids including Australian crop mired (Sidnia kinbergi) and potato mirid (Calocoris norvegicus) (Schroeder \& Clifford 1995). Significant benefits from controlling mirids in white clover with synthetic pyrethroids were demonstrated by Schroeder et al. (1996, 1998). Aphids such as cabbage aphid (Brevicoryne brassicae) can be a problem on brassica seed crops but seed treatment at sowing as well as insecticides are used to control these. Diamondback moth (Plutella xylostella) can be a serious problem on brassicas in some years and often requires insecticide treatment. Today, insects remain a problem that can be managed with regular crop monitoring and use of appropriate bee safe insecticides.

\section{Research \& Development (R\&D)}

Early seed production R\&D was undertaken by the Department of Agriculture (DOA) and later by the Ministry of Agriculture and Fisheries (MAF). Key science was initially led by R.H.M Langer \& J. FieldDodgson (Lincoln College), E.O.C Hyde (DSIR Grasslands), and later by Murray Hill \& John Hampton (MAF \& Massey University) and Rod Thomas (Massey University). Ray Brougham, DSIR Grasslands, re-created a herbage seed research group in 1972 with scientists Peter Clifford (legume), Ken Brown (grasses) and followed by Phil Rolston in 1979. Two bibliographies on NZ seed research have been compiled by Rowarth (1989) and Rowarth et al. (1998c). Seed production research was largely government funded until 2000, and since then applied 
seed production research has been funded by FAR with several larger seed companies funding research to support their own cultivars. Basic research currently funded by government has focused on gene mapping of seed yield and endophyte transmission into seeds. New research projects are becoming more focused on the physiology of carbohydrate and nitrogen allocation between reproductive and vegetative growth. In herbage seed crops, there is biologically a large wastage of reproductive potential with less than $25 \%$ of florets producing saleable seeds and half the developing seeds failing to mature in the last 2 weeks of seed fill. The challenge for research is to understand the causes of wasted reproductive potential and to increase the percent conversion of florets to saleable seeds, and to understand the wide variation in seed yields that occur within and between farms using broadly similar inputs and managements.

\section{Extension}

A free advisory service was available for seed growers from the DOA/MAF until 1992. When the Advisory Service moved to paid consultancies, a number of private advisors set up as arable specialists and many continue to service grower clients to the present day. During this period the larger seed companies developed technical specialists to either service contract growers directly or to support company reps that serviced growers. The Commodity Levy Act 1990 led the Herbage Sub Section of Federated Farmers (HSSFF) to seek a mandate from seed growers to collect a compulsory levy. In 1995, the HSSFF created the Foundation for Arable Research (FAR) as a grower levy funded organisation that has become the major extension provider to seed growers.

\section{Conclusion}

Forage seed is the delivery vehicle for new plant genetics to the pastoral sector and a strong seed industry is a corner stone to a strong pastoral industry. Applying science and technology has been critical to the successful development of the forage seed industry for New Zealand, ensuring that economics of production have remained competitive internationally and with other land use options available to growers. The impacts of plant breeding and cultivar availability, mechanisation and agrichemicals have all had major impacts on transforming the industry over the 75 year period reviewed. Seed yields continue to increase but there is still a wide gap between average crops and highest yielding crops. Understanding crop physiology (flowering control, carbohydrate allocation) at a biochemical and gene-regulatory level, new biotechnologies (genetically modified organisms) and environmental sustainability are the issues that will have a major influence in the future.

\section{REFERENCES}

AgriQuality 2004. Seed Certification Statistics 20032004. AgriQuality New Zealand Ltd.

AgriQuality 2005. Seed Certification 2005-2006 Field and laboratory standards. AgriQuality Ltd, Ministry of Agriculture and Fisheries. 77 pp.

Brown, K.R. 1980. Recent grass seed production studies in Canterbury. Herbage Seed Production. Grassland Research and Practice 1: 12-14.

Claridge, J.H. 1972. Arable Farm Crops of New Zealand (DSIR; AH Reed Wellington)

Clifford, P.T.P. 1985. Effects of leaf area on white clover seed production. Producing Herbage Seeds. Grassland Research and Practice Series 2: 25-32.

Clifford, P.T.P. 1987. Producing high seed yields from high forage producing white clover cultivars. Journal of Applied Seed Production 5: 1-9.

Clifford, P.T.P. 1998. Trifolium repens L. (White clover) in New Zealand.pp 385-393 In: Forage Seed Production Vol 1. Temperate Species, Eds D.T. Fairey and J.G. Hampton, CAB International.

Clifford, P.T.P.; Rolston, M.P. 1990. Mineral nutrition requirement for white clover seed production. Journal of Applied Seed Production 8: 54-58.

Clifford, P. T. P.; McCartin, S. J. M. 1985. Effects of pre-harvest treatment and mower and header types on seed loss and hard seed content at mowing, recovery, and separation when harvesting a white clover seed crop. New Zealand Journal of Experimental Agriculture 13: 307-316.

Clifford, P.T.P.; Sparks, G.A.; Woodfield, D.R. 1995. The intensifying requirements for white clover cultivar change. White Clover: New Zealand's Competitive Edge. Grassland Research and Practice Series 6: 19-24.

DeFilippi, J.M.; Hampton, J.C.; Rolston, M.P.; Rowarth, J.S. 1996. Effect of nitrogen and irrigation on blind seed diseases in perennial ryegrass (Lolium perenne L) cv. Grasslands Nui. Journal of Applied Seed Production 14: 81-84.

Donovan, B.J. 2006. Apoidea, Fauna of New Zealand series, Landcare Research New Zealand Ltd. in press.

Donovan, B.J.; Macfarlane R.P. 1984. Bees and Pollination. In: New Zealand Pests and Beneficial Insects Ed. R.R Scott, Lincoln University College of Agriculture, Christchurch, New Zealand.

Donovan, B.J.; Read, P.E.C. 1988. Efficacy of lucerne leafcutting bees as pollinators of Lucerne in New Zealand. Pp 257-264 In: Proceedings 5th Australasian Conference on Grassland Invertebrate Ecology.

Easton, H.S. 1999. Endophyte in New Zealand ryegrass 
pastures, an overview. Ryegrass Endophyte: An Essential New Zealand Symbiosis. Grasslands Research and Practice Series 7: 1-10.

FAR. 1999. Herbicides for 2nd year white clover (H99/ 12). Report for Foundation for Arable Research prepared by B.L. McCloy; NZ Arable.

FAR. 2004. Herbicides on 2nd year white clover (H04/ 03). Report for Foundation for Arable Research prepared by B.L. McCloy and M.R. O'Hara, NZ Arable.

FAR. 2005. South Canterbury seed growers survey (H05/16). Report for Foundation for Arable Research prepared by M.P. Rolston, AgResearch..

Hampton, J.C. 1986. The effect of chlormequat chloride applications on seed yield of perennial ryegrass (Lolium perenne L.). Journal of Applied Seed Production 4: 5-7.

Hampton, J.C.; Scott, D.J. 1980. Blind seed disease of ryegrass in New Zealand. II. Nitrogen fertiliser: effect on incidence and possible mode of action. New Zealand Journal of Agriculture Research 23: 143147.

Hampton, J.C.; Hebblethwaite, P.D. 1984. Experiments with vegetative tiller manipulation in perennial ryegrass (Lolium perenne) seed crops by the application of growth regulator. Journal of Applied Seed Production 2: 1-7.

Hampton, J.C.; Scott, D.J. 1990. New Zealand seed certification. Plant Varieties and Seeds 3:173-180.

Hill, M. 1999. The drying and storage of grains and herbage seed. A Foundation for Arable Research Publication, Lincoln. 210 pp.

Kerse G.W.; Ballard D.L. 1989. Cyproconazole - a new DMI fungicide. Proceedings of the New Zealand Weed and Pest Control Conference 42: 114-118.

Langer, R.H.M. 1980. Growth of the grass plant in relation to seed. Herbage Seed Production. Grassland Research and Practice Series 1: 6-11.

Latch, G.C.M. 1980. Importance of diseases in herbage seed production. Herbage Seed Production. Grassland Research and Practice Series 1: 36-40.

Levy, E. B. 1970. Grasslands of New Zealand, Government Printer Wellington $374 \mathrm{pp}$

Mather, R.D.J.; Melhuish, D.T.; Herlihy, M. 1996. Trends in the global marketing of white clover cultivars. White clover: New Zealand's Competitive Edge. Grassland Research and Practice Series 6: 714.

McCloy, B.; Rolston, P. 2005. Nitrogen Budgets in Ryegrass Seed Crops 2004/05. Report H04/05 to Foundation for Arable Research July 2005. 20p

Palmer T.P. 1983. Forage Brassicas. Plant Breeding in New Zealand Ed. G.S. Wratt and H.C. Smith, DSIR in association with Butterworths, Wellington.
Pyke, N.B.; Rolston, M.P.; Woodfield, D.R. 2004. National and export trends in herbage seed production. Proceedings of the New Zealand Grassland Association 66: 95-102.

Rolston, M.P.; Clifford, P.T.P. 1989. Herbage seed: production and research - a review of 50 years. Proceedings of the New Zealand Grassland Association 50: 47-53.

Rolston, M.P.; Archie, W. 1999. Competition effect of wild oat and annual poa in first year ryegrass seed crops. Pp 241-245 In: Proceedings 4th International Herbage Seeds Conference, Italy.

Rolston, M.P.; Brown, K.R.; Hare, M.D.; Young, K.A. 1985. Grass seed production: weeds, herbicides and fertiliser. Producing Herbage Seeds. Grassland Research and Practice Series 2: 15-22.

Rolston, M.P.; Rowarth, J.S.; DeFillippi, J.M; Archie, W.J. 1994. Effect of water and nitrogen on lodging, head numbers and seed yield of high and nil endophyte perennial ryegrass. Proceedings of the Agronomy Society of New Zealand 24: 91-94.

Rolston, M.P.; McCloy, B.L.; Pyke, N.B. 2004. Grass seed yields increased with plant growth regulators and fungicides. Proceedings of the New Zealand Grassland Association 66: 127-132.

Rowarth, J.S. 1989. Bibliography of New Zealand research on herbage seed production. New Zealand Journal of Agricultural Research 32: 551-581.

Rowarth, J.S.; Hampton, J.G; Hill, M.J. 1998a. Herbage seed production in New Zealand: past, present and future. Pp 1-21 In: Practical herbage seed crop management Ed J.S Rowarth, Lincoln University Press.

Rowarth, J.S.; Boelt, B.; Hampton, J.C.; Marshall, A.H.; Rolston, M.P.; Sicard, G.; Silberstein, T.B.; Sedcole, J.C.; Young, W.C. 1998b. The relationship between applied nitrogen, nitrogen concentration in herbage and seed yields in perennial ryegrass (Lolium perenne L.). 1. Grasslands Nui at five sites around the globe. Journal of Applied Seed Production 16: 105114.

Rowarth, J.S.; Hampton, J.G.; Hill, M.J. 1998c. Bibliography of New Zealand research on herbage seed production 1988-1997. New Zealand Journal of Agricultural Research 41: 447-462.

Rowarth, J.; Rolston, M.P.; Johnson, A. 1990a. Weed seed occurrence in ryegrass seedlots. Pp 125-129 In: Proceedings of the 43rd New Zealand Weed and Pest Control Conference.

Rowarth, J.S.; Johnson, A.; Clifford, P.T.P.; Rolston, M.P. 1990b. Weed seed contamination in white clover seedlots. Proceedings of the New Zealand Grassland Association 52: 99-104.

Schroeder, N.C.; Baird, D.B.; Upritchard E.A.; 
Simeonidis, A. 1996. Lambda-cyhalothrin: An insecticide for hemipteran pest control in white clover seed crops. Pp 304-308 In: Proceedings of the 49th New Zealand Plant Protection Conference.

Schroeder, N.C.; Chapman R.B; Clifford P.T.P. 1998. Effect of potato mirid (Calocoris norvegicus) on white clover seed production in small cages. Journal of Agricultural Research. 41: 111-116.

Schroeder, N; Clifford, P. 1995. The incidence of insect pests and their Arthropod predators in 24 Canterbury white clover crops. White Clover: New Zealand's Competitive Edge. Grassland Research and Practice Series 6: 29-33.

Trought, T.E.T. 1980. Pests in herbage seed production. Herbage Seed Production. Grassland Research and Practice Series 1.

Wilson, J. 2004. Tractors across New Zealand, a history of working the land. Whitcoulls Ltd. China. 